\title{
Class III nonsurgical treatment using indirect skeletal anchorage: A case report
}

\author{
Jun Young Choi, ${ }^{\text {a }}$ DDS, Won Hee Lim, ${ }^{\mathbf{b}}$ DDS, MS, PhD \\ Youn Sic Chun, ${ }^{\text {c }}$ DDS, MSD, PhD
}

\begin{abstract}
Treatment of adult patients with Class III malocclusion frequently requires a combined orthodontic and surgical approach. However, if for various reasons, nonsurgical orthodontic treatment is chosen, a stable outcome requires careful consideration of the patient's biologic limitation. This case presents the orthodontic treatment of an adult with a Class III malocclusion, which was treated nonsurgically using indirect skeletal anchorage. (Korean J Orthod 2008;38(1):60-7)
\end{abstract}

Key words: Class III, Nonsurgical treatment, Indirect skeletal anchorage, Miniscrew

\section{INTRODUCTION}

Surgical approach is considered to be one of the best alternatives in most cases of adult patients with class III malocclusion. Depending on the amount of skeletal discrepancy, surgical correction may consist of mandibular set-back, or maxillary advancement, or a combination of mandibular and maxillary surgery.' However, if for various reasons, surgical treatment is contraindicated, orthodontic camouflage treatment may be a treatment option. Extraction of the mandibular first premolars and the maxillary second premolars and the use of Class III elastics have been used successfully for the nonsurgical correction of Class III malocclusions. ${ }^{2}$ When a nonsurgical treatment is chosen, a stable

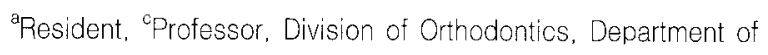
Dentistry, Ewha Womans University Mokdong Hospital

${ }^{b}$ Assistant Professor, Department of Orthodontics, School of

Dentistry, Seoul National University

Corresponding author: Youn Sic Chun.

Division of Orthodontics, Department of Dentistry, College of Medicine. Ewha Womans University, 911-1 Mokdong, Yang

Cheon-Gu Seoul 158-710. Korea.

+8222650 5021; e-mail, yschun@ewha.ackr.

Received December 26, 2006; Last Revision March 17, 2007; Accepted March 19, 2007. outcome requires careful consideration of the patient's biologic limitation, to prevent adverse consequences such as traumatic incisor occlusion, incisor mobility and gingival recession. ${ }^{3,4}$

There are two basic ways to use miniscrews for orthodontic anchorage. Target teeth may be directly connected to the miniscrew by elastics or power chain in direct anchorage, while the miniscrew is connected to the adjacent tooth by $0.019 \times 0.025$ stainless-steel wire in indirect anchorage. The tooth connected to the miniscrew provides a strong and stable anchorage, which is similar to an ankylosed tooth. After placement of a single miniscrew between the premolars on each side, conventional edgewise mechanics can be applied just to the anterior teeth and the first premolars, without the need to bond anything on the posterior teeth. ${ }^{5-8}$

\section{CASE REPORT}

The patient was a 38-year-old Asian male whose chief concern was anterior crossbite and an unesthetic smile due to the extrusion of upper and lower anterior teeth. He had a class III malocclusion with a $2.1 \mathrm{~mm}$ anterior crossbite and facial imbalance. His oral hygiene was excellent and his medical and dental histories were unremarkable. 


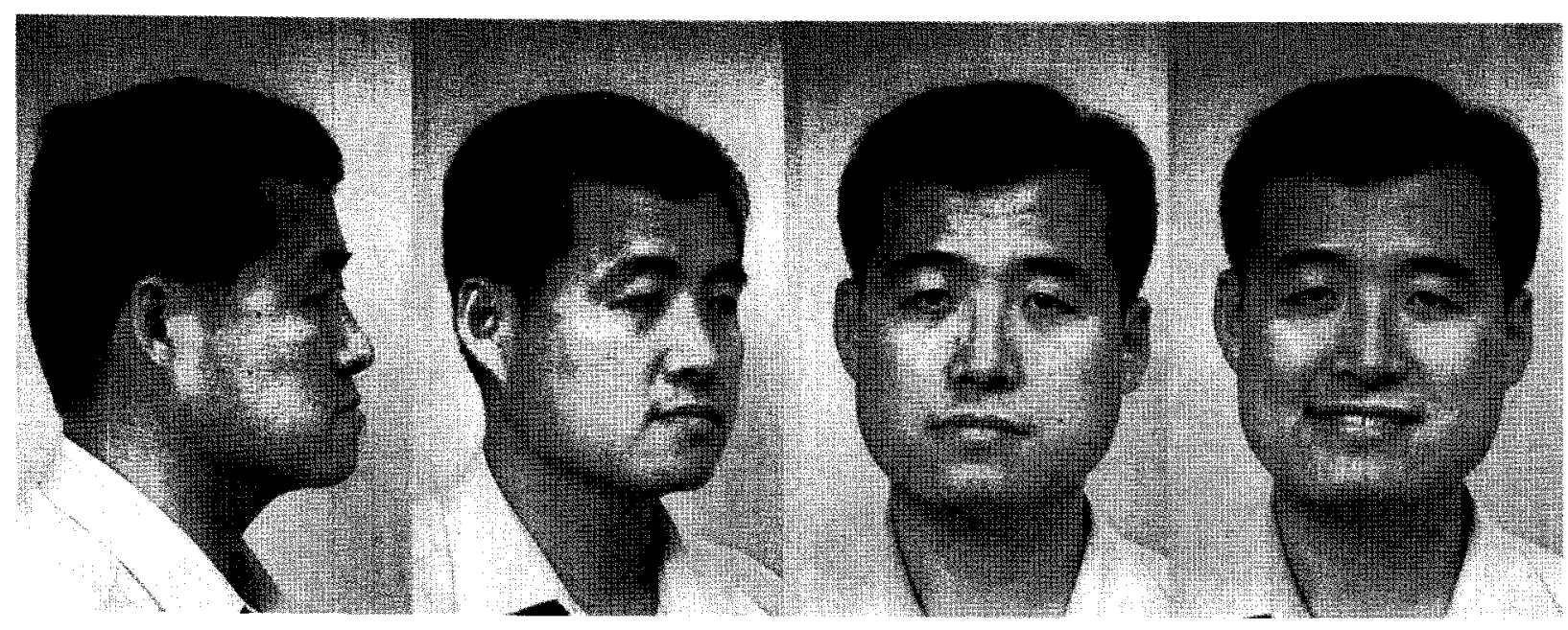

Fig 1. Pretreatment facial photographs.

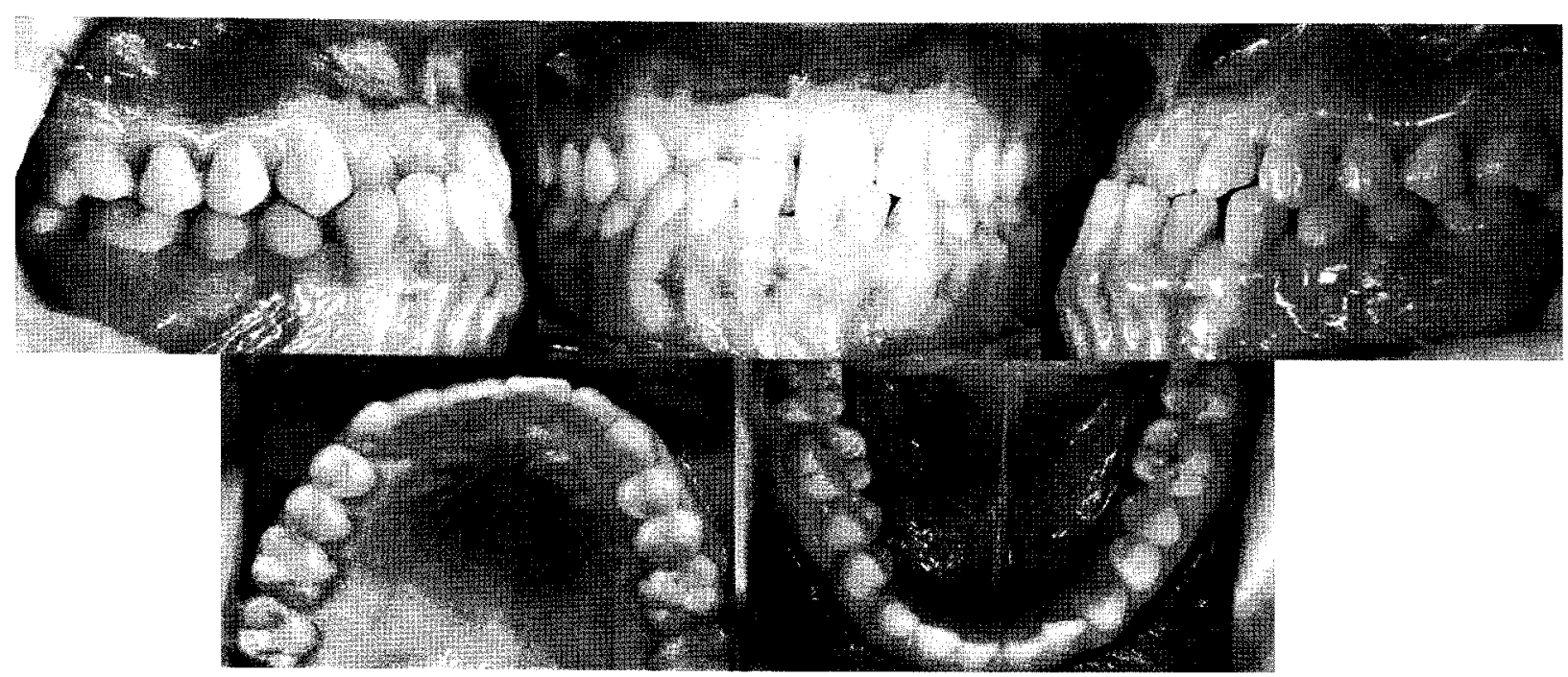

Fig 2. Pretreatment intraoral photographs.

\section{ETIOLOGY AND DIAGNOSIS}

The facial photographs (Fig 1) showed a prognathic mandible and a Class III appearance. The pretreatment intraoral photographs and study models (Figs 2 and 3) showed Class III molar and canine relationships, 2.1 $\mathrm{mm}$ anterior crossbite and $5.3 \mathrm{~mm}$ of lower anterior spacing. The panoramic radiograph (Fig 4) showed that all teeth were present except for the third molars. Cephalometric analysis (Fig 5) revealed a Class III skeletal pattern. The ANB angle of -4 and the SNB angle of 85 indicated a prognathic mandible. The FMA angle of 14 was characteristic of a low mandibular plane. The IMPA angle of 82 confirmed linguoversion of the lower anterior teeth. The nasolabial angle of 88 was normal. The Wits measurement of $-10 \mathrm{~mm}$ confirmed the skeletal imbalance. The cephalometric values are summarized in the Table 1.

Based on these findings, this patient's malocclusion can be said to be due primarily to a skeletal difference between the maxilla and the mandible, which resulted in dental tipping and extrusion on the anterior areas. 


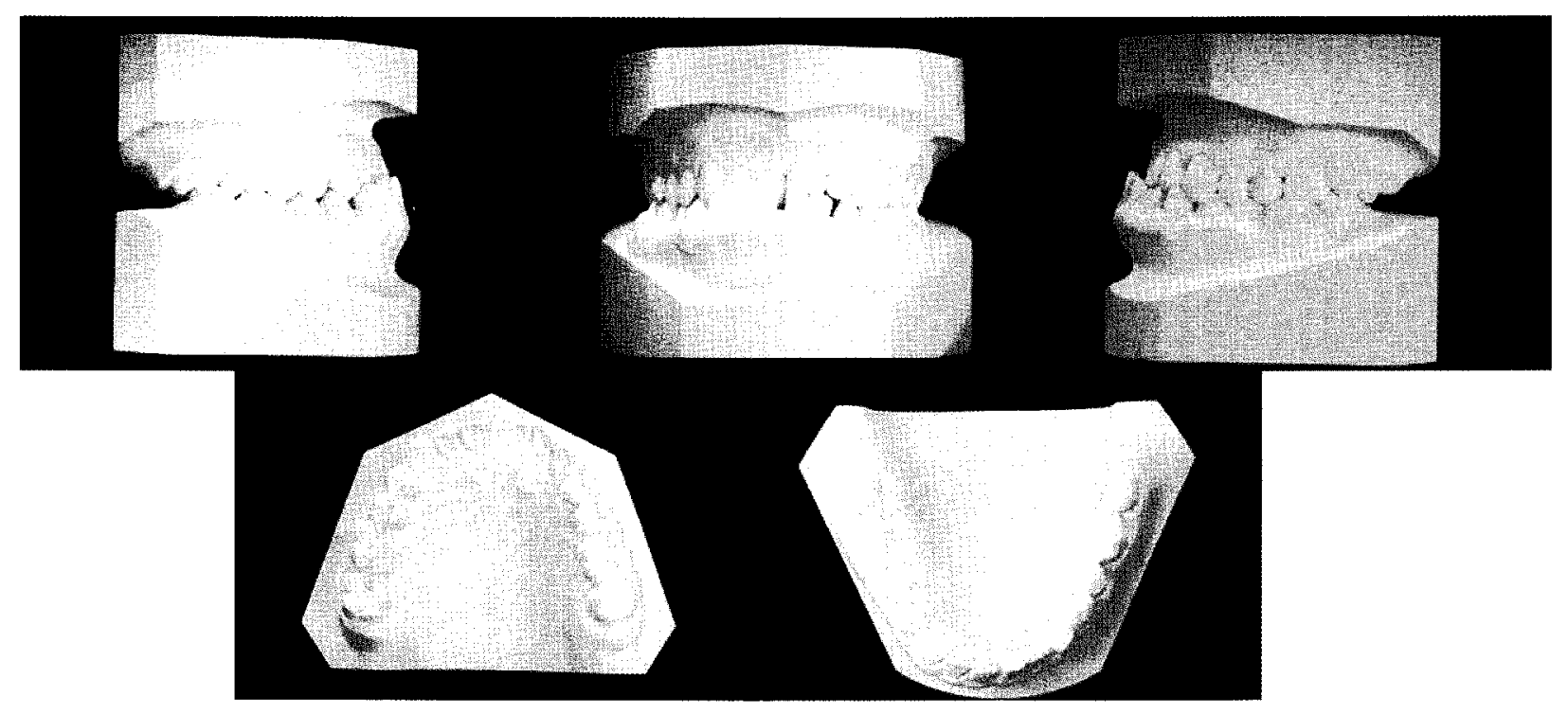

Fig 3. Pretreatment dental casts.

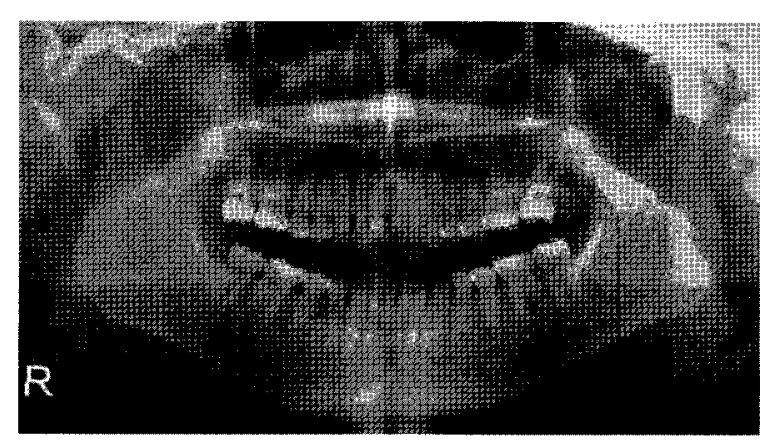

Fig 4. Pretreatment panoramic radiograph.

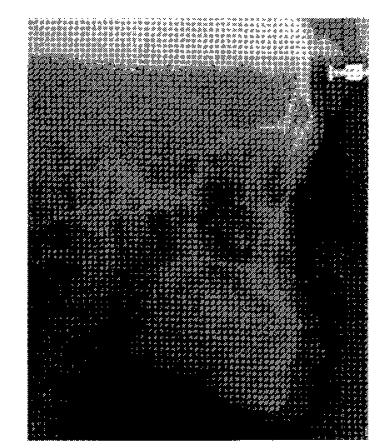

Fig 5. Pretreatment cephalometric radiograph.

Table 1. Cephalometric summary

\begin{tabular}{|c|c|c|c|c|}
\hline W & Measirement & Nonns & mitad & W \\
\hline Maxilla to cranial base & SNA $\left(^{\circ}\right)$ & 82 & 81 & 81 \\
\hline Mandible to cranial base & $\operatorname{SNB}\left({ }^{\circ}\right)$ & 80 & 85 & 85 \\
\hline \multirow[t]{2}{*}{ Maxillomandibular relations } & $\mathrm{ANB}\left({ }^{\circ}\right)$ & 2 & -4 & -4 \\
\hline & Wits appraisal $(\mathrm{mm})$ & -2 & -8 & -8 \\
\hline Vertical height & FMA $\left(^{\circ}\right)$ & 23 & 14 & 14 \\
\hline \multirow[t]{2}{*}{ Maxillary and mandibular incisor position } & $\mathrm{U} 1$ to $\mathrm{SN}\left({ }^{\circ}\right)$ & 103 & 116 & 117 \\
\hline & IMPA $\left(^{\circ}\right)$ & 93 & 82 & 70 \\
\hline \multirow[t]{2}{*}{ Soft tissue } & Lower lip to E-line (mm) & $0+2$ & 2 & -1 \\
\hline & Nasolabial angle $\left({ }^{\circ}\right)$ & 85 & 88 & 86 \\
\hline Other & Interincisal angle $\left(^{\circ}\right)$ & 131 & 134 & 148 \\
\hline
\end{tabular}



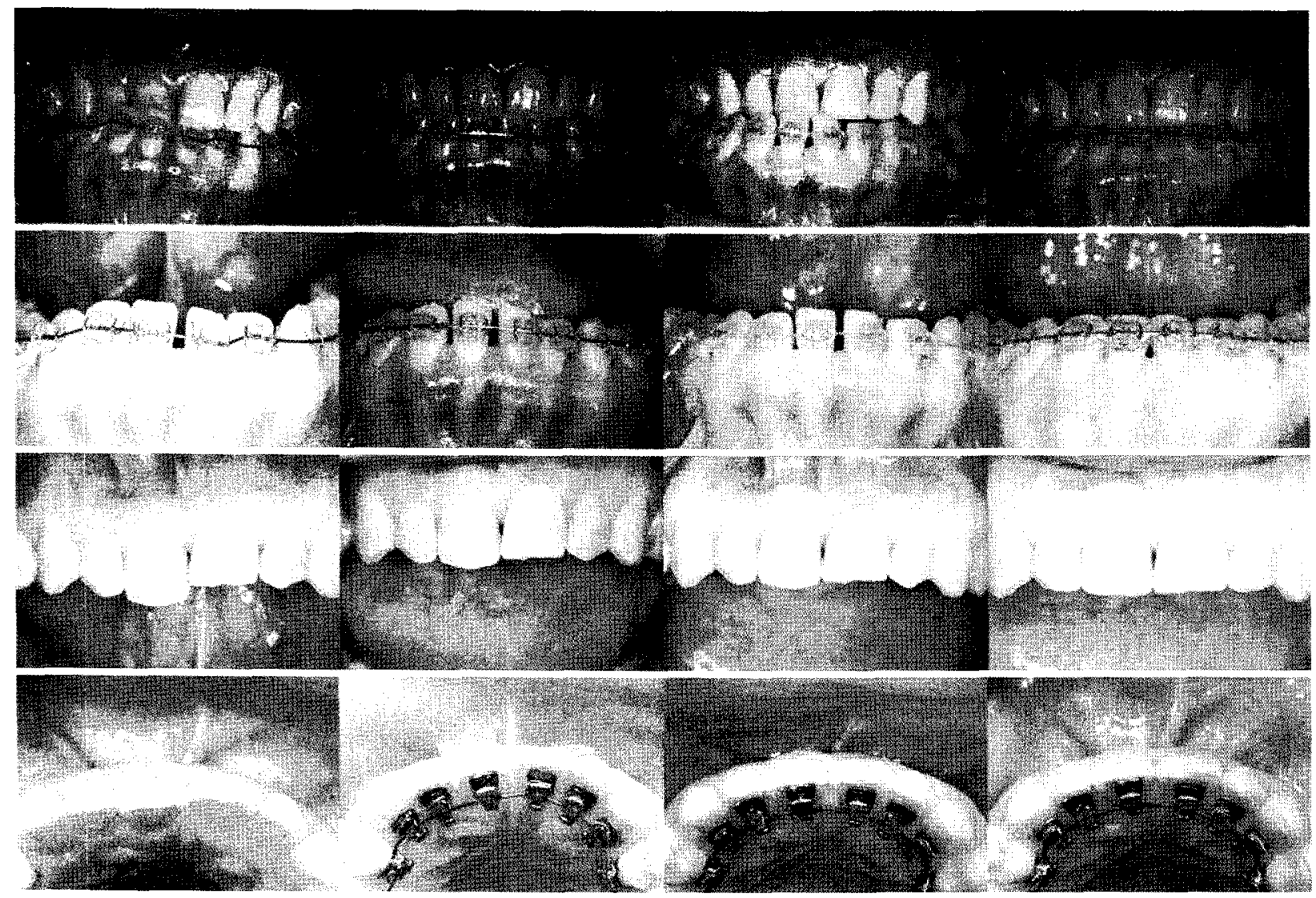

Fig 6. Treatment progress

\section{TREATMENT OBJECTIVES}

1, Preserve occlusion of posterior teeth; 2, Align and level the anterior teeth; 3, Eliminate lower anterior spacing; 4, Correct the anterior crossbite; 5, Establish normal overjet and overbite; 6, Coordinate the arch forms.

\section{TREATMENT ALTERNATIVES}

Based on the severe skeletal discrepancy, orthognathic surgery was strongly recommended, because it was likely to provide a better esthetic result. However, the patient did not want a surgical approach. Consequently, a nonsurgical treatment plan was suggested, with the limitation that it would correct only the anterior crossbite. The options and details were fully discussed with the patient before orthodontic treatment.

\section{TREATMENT PROGRESS}

Four miniscrews (OSAS, $1.6 \times 8.0 \mathrm{~mm}$ ) were placed between the first and second premolars in the maxilla and the mandible under local anesthesia. The axes of the roots were evaluated on the periapical and panoramic $\mathrm{x}$-rays to determine the ideal sites for miniscrew placement. A miniscrew was connected to the buccal surface of the first premolar by $0.019 \times$ 0.025 stainless steel wire using conventional composite resin after sandblast etching. The tooth connected to the miniscrew provides a strong and stable anchorage, which is similar to an ankylosed tooth. The use of indirect skeletal anchorage allowed conventional edgewise mechanics to be applied only on the anterior teeth and the first premolars without bonding the posterior teeth. In the mandible, 0.018 slot straight-wire fixed appliances were placed, and 0.018 slot lingual 


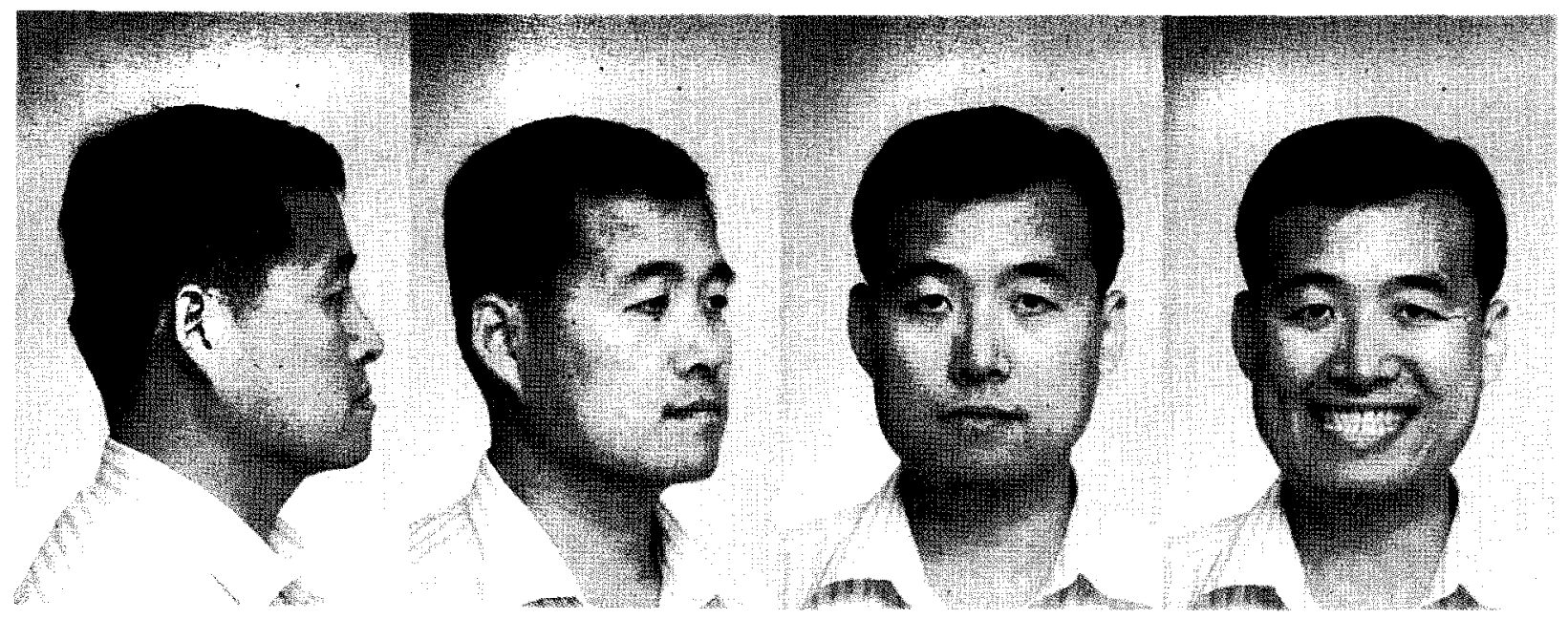

Fig 7. Posttreatment facial photographs.

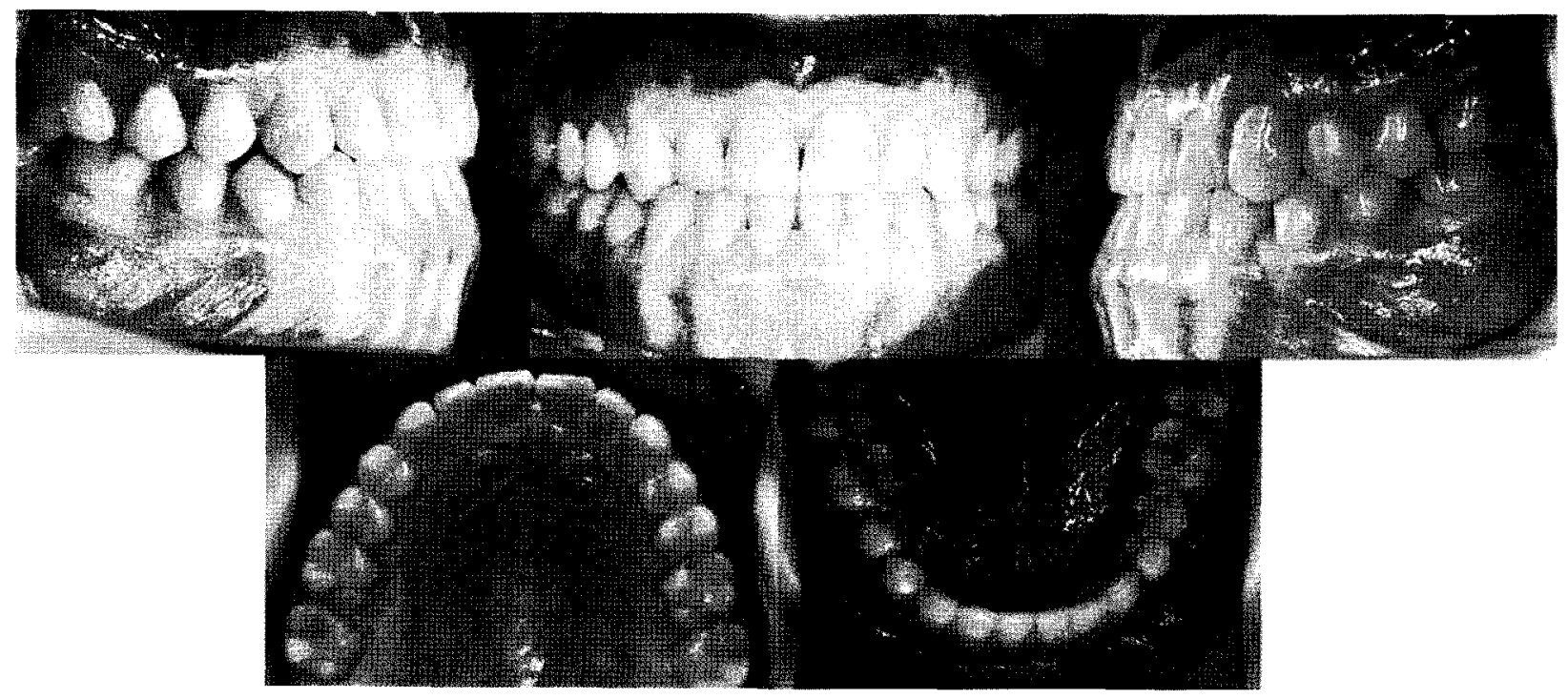

Fig 8. Posttreatment intraoral photographs.

fixed appliances were placed in the maxilla because the patient did not want to make the appliances to be visible in the maxillary dentition.

The extruded maxillary anterior teeth and mandibular anterior teeth were intruded to the level of the first premolars using sequential NiTi arch wires to allow the mandibular anterior teeth to be retracted without occlusal interference. Space closure and retraction were done concurrently using elastic chains in the mandible. The malocclusion correction was detailed after a positive overjet was obtained (Fig 6).

\section{TREATMENT RESULT}

The facial photographs (Fig 7) showed no change in the facial profile. Despite the Class III skeletal pattern, the patient very pleased with his dental improvement. The dental casts (Figs 8 and 9) showed that the extruded maxillary right central incisor and mandibular anterior teeth were intruded. A positive overjet was 


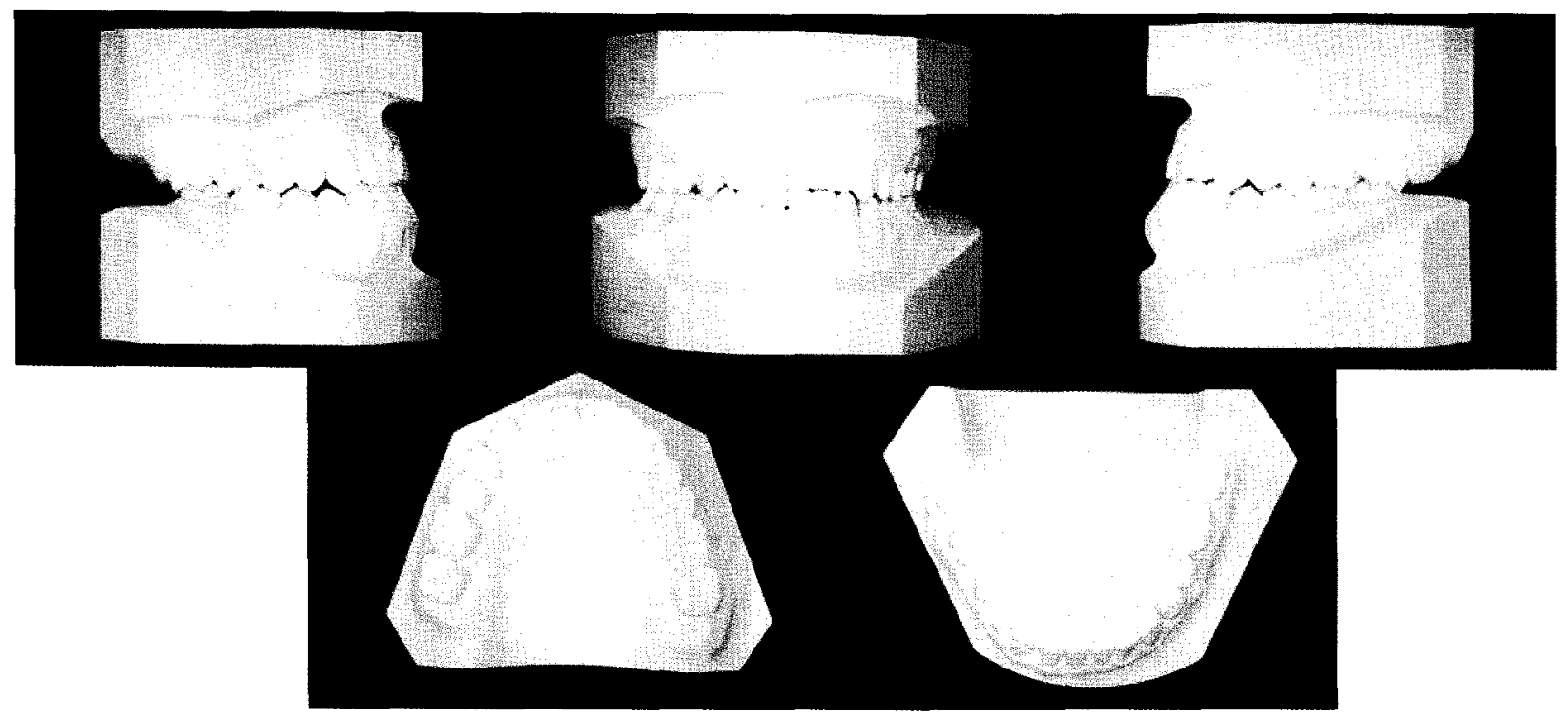

Fig 9. Posttreatment dental casts.

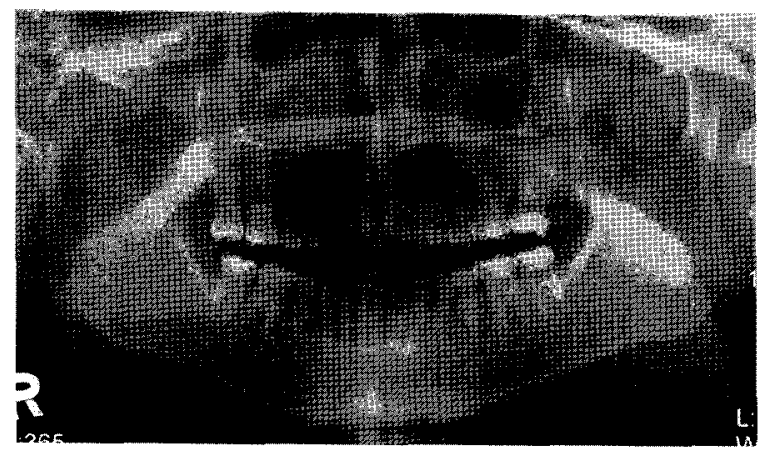

Fig 10. Posttreatment panoramic radiograph.

established, and overbite was reduced. The mandibular incisors were significantly retroclined.

The posttreatment cephalometric analysis and composite tracing (Figs 10 - 12) confirmed that there were no skeletal changes in either the maxilla or the mandible. The mandible is still prognathic. The FMA angle was also unchanged, which means that the vertical position of posterior teeth on both the maxilla and mandible was the same after correction of the crossbite. The mandibular incisors were uprighted to an IMPA angle of 70. The proclination of the maxillary incisors was almost maintained. The extruded maxillary right central incisor was intruded, and the lower incisors were both intruded and retracted.

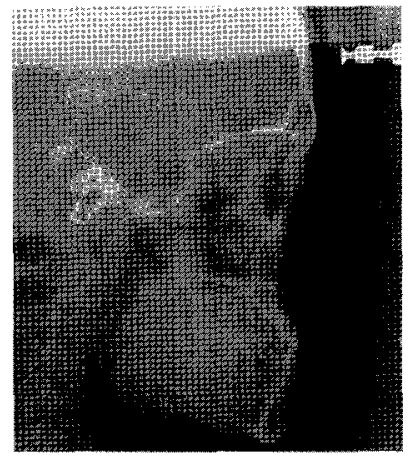

Fig 11. Posttreatment cephalometric radiograph.

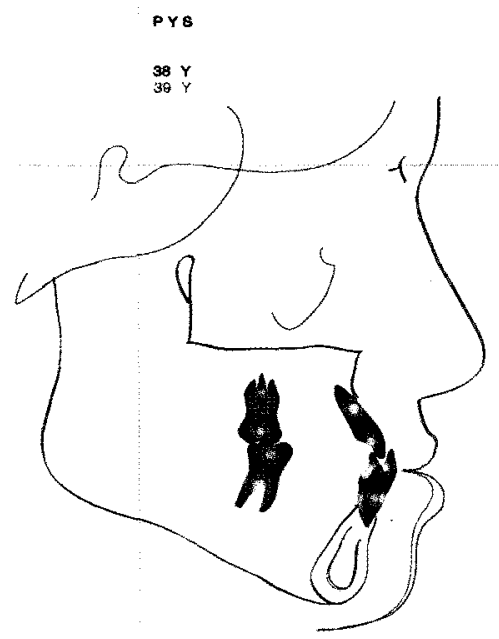

Fig 12. composite tracing of before and after treatment. 


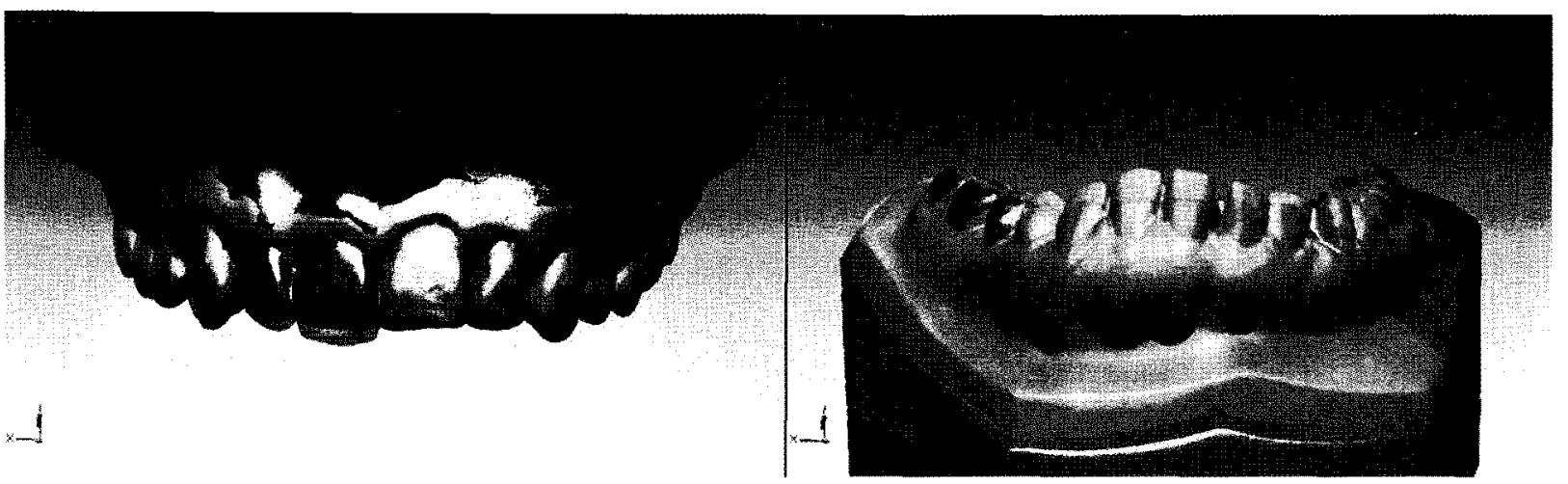

Fig 13. 3D-Model superimposition.

The superimpositions of 3-D images before and after treatment (Fig 13) revealed that the extruded maxillary right central incisor was $1 \mathrm{~mm}$ intruded, and the lower incisors were $2 \mathrm{~mm}$ intruded and $5 \mathrm{~mm}$ retracted.

Bonded retainers were placed after debonding. The total length of treatment time was 12 months.

\section{DISCUSSION}

It appeared that orthognathic correction would be the treatment of choice in this case as it would resolve the skeletal discrepancy and improve the soft tissue profile. $^{9-11}$ However, because the patient did not want any surgical involvement, the treatment was started with orthodontic treatment only. This treatment brought only dental correction.

To more accurately assess the dental change, casts before and after treatment were scanned by an Orapix 3-D scanner and the real images were obtained through a 3-D image viewer (Rapid-Form 2004). The 3-D images before and after treatment were superimposed by a surface to surface matching registration method. To assess spatial tooth movement from serial artificial models, the physical superimposition was registered either on the palatal rugae on the maxilla or on the posterior teeth of the mandible. Palatal rugae were considered to be good registration points because they do not change. ${ }^{12}$ In the mandible, the posterior teeth were used for registration in this case because the cephalometric analysis showed no change in their position after treatment.

Indirect skeletal anchorage was used to obtain a strong anchorage and to preserve good occlusion of posterior teeth. Fixed appliances were bonded to only the anterior teeth and first premolars in this case, in order to preserve the posterior occlusion. This is one of the advantages of indirect skeletal anchorage. ${ }^{13}$ Indirect skeletal anchorage also makes it possible to place a miniscrew where there is better access, and where it will not affect or damage any anatomical structures. ${ }^{14}$ Indirect anchorage was also more convenient, and facilitated a setup for more precise tooth movement. ${ }^{15-18}$

One concern with the nonsurgical approach was the necessity of uprighting the lower incisors over the basal bone to get a positive overjet. The patient did not show any recession on his anterior teeth during the orthodontic treatment. However, continuous monitoring and oral hygiene care were necessary. ${ }^{18}$ It has also been reported that intrusion of anterior teeth may cause root resorption. ${ }^{19-21}$ In this case, no root resorption occurred. The gingival margin of the maxillary anterior teeth was leveled when the teeth were leveled. However, this was not done perfectly because attrition was present. The patient did not want perfect gingival leveling, because additional restorative treatment is generally done afterwards.

- 국문초록 -

$$
\begin{gathered}
\text { 간접 골성 고정원을 이용한 } \\
\text { 골격성 } \||| \text { 급 부정교합의 절충 치험례 } \\
\text { 최 준 영·임 원 희·전 윤 식 }
\end{gathered}
$$

성인에서의 골격성 111 급 부정교합의 치료의 원칙은 하악골의 후방이동을 동반한 수술적 교정치료이나, 다양한 문제로 인해 
수술적 방법을 선택하기 어렵고 부조화의 정도가 심하지 않은 환자의 경우 비수술적 절충 치료를 선택할 수 있다. 비수술적 절충치료를 시행하는 경우 교정치료의 한계와 치주적인 부분에 대한 주의가 필요하다. 본 교실에서는 간접 골성 고정원을 이 용하여 성인에서의 골격성 III 급 부정교합을 비수술적으로 절 충 치료 하였기에 보고하고자 한다.

주요 단어: || $\mid$ 급 부정교합, 절충치료, 간접 골성 고정원, 교정 용 미니스크류

\section{REFERENCES}

1. Popp TW, Gooris CG, Schur JA. Nonsurgical treatment for a Class IIl dental relationship: A case report. Am J Orthod Dentofacial Orthop 1993;103:203-11

2. Proffit WR. Contemporary orthodontics. St Louis: Mosby; 1986, p. 200-207

3. Stellzig-Eisenhauer A, Lux CJ, Schuster G. Treatment decision in adult patients with Class III malocclusion: orthodontic therapy or orthognathic surgery? Am J Orthod Dentofacial Orthop 2002;122:2738.

4. Graber TM. Orthodontics, principles and practice. Philadelphia: Saunders; 2005. p. 128-130.

5. Kanomi R. Mini-implant for orthodontic anchorage. J Clin Orthod 1997;31:763-7.

6. Costa A, Raffainil M, Melsen B. Miniscrews as orthodontic anchorage: A preliminary report. Int $\mathrm{J}$ Adult Orthodon Orthognath Surg 1998;13:201-9.

7. Park HS, Bae SM, Kyung HM, Sung JH. Micro-implant anchorage for treatment of skeletal Class I bialveolar protrusion. J Clin Orthod 2001;35:417-22.

8. Celenza F, Hochman M. Absolute anchorage in orthodontics: Direct and indirect implant-assisted modalities. J Clin Orthod 2000;34: $397-402$
9. Jensen AC, Sinclair PM, Wolford LM. Soft tissue changes associated with double jaw surgery. Am J Orthod Dentofacial Orthop 1992;101: 266-75.

10. Enacar A, Taner T, Toroglu S. Analysis of soft tissue profile changes associated with mandibular setback and double-jaw surgeries. Int $\mathrm{J}$ Adult Orthodon Orthognath Surg 1999;14:27-35.

11. Chew MT. Soft tissue and hard tissue changes after bimaxillary surgery in Chinese class III patients. Angle Orthod 2005;75:959-63.

12. Bailey LT, Esmailnejad A, Almeida MA. Stability of the palatal rugae as landmarks for analysis of dental casts in extraction and nonextraction cases. Angle Orthod 1996;66:73-8.

13. Chang YJ, Lee HS, Chun YS. Microscrew anchorage for molar intrusion. J Clin Orthod 2004;38:325-30.

14. Yun SW, Lim WH, Chun YS. Molar control using indirect miniscrew anchorage. J Clin Orthod 2005;39:661-4.

15. Aldo G, Fabiana M, Francesca S, Claudio A. Miniscrew treatment of ectopic mandibular molars. J Clin Orthod 2003;37:380-3.

16. Park HS, Kyung HM, Sung JH. A simple method of molar uprighting with micro-implant anchorage. J Clin Orthod 2002;36: 592-6.

17. Kyung SH, Choi JH, Park YC. Miniscrew anchorage used to protract lower second molars into first molar extraction sites. $\mathrm{J}$ Clin Orthod 2003;37:575-579

18. Sam K, Rabie AB, King NM. Orthodontic intrusion of periodontally involved teeth. J Clin Orthod 2001;35:325-30.

19. Linge BO, Linge L. Apical root resorption in upper anterior teeth. Eur J Orthod 1983;5:173-83.

20. McFadden WM, Engstrom C, Engstrom H, Anholm JM. A study of the relationship between incisor intrusion and root shortening. Am J Orthod Dentofacial Orthop 1989;96:390-6.

21. Costopoulos G, Nanda R. An evaluation of root resorption incident to orthodontic intrusion. Am J Orthod Dentofacial Orthop 1996;109: $543-8$. 